\title{
Review
}

\section{Political political theory: Essays on institutions}

\author{
Jeremy Waldron \\ Harvard University Press, Cambridge, MA and London, 2016, 416pp., \\ ISBN: 978-0-674-74385-4
}

Contemporary Political Theory (2017) 16, 553-556. doi:10.1057/s41296-016-0081-z; advance online publication 16 November 2016

Recently political theorists and philosophers have taken a greater interest in theorising real-world politics. Practice-dependent methods, political realism, and non-ideal theory exemplify and contribute to this shift. In this context, Jeremy Waldron's Political Political Theory can be considered as another move in these debates. In a similar vein to realists, Waldron argues that too much time is being devoted to theorising justice. In the everyday practice of politics, justice or any other ethical or political aim remains the object of disagreement. Consequently, Waldron argues, 'we need to inquire into the structures that are to house and redefine our disputes and the processes that are to regulate the way we resolve them' (p. 5). More specifically, political theorists should explore 'the foundations' of modern democratic institutions and constitutional principles, such as political parties and federalism. In this book, which consists of previously published essays edited for this collection and three completely new chapters, Waldron's insightful reflections uncover many nuances in principles often taken for granted in designing political institutions.

The book consists of three parts. The first part is the introductory chapter, which sets the theoretical stage for the rest of the collection. Waldron's point of departure is that political theory should take seriously that disagreement about many concepts, such as justice and freedom, is the reason for politics. Political institutions and constitutional principles are the real-world normative tools to address such disagreements. Because institutions are real-world constructs rather than abstract entities, this has the methodological implication that political philosophy should take into account empirical research on their real-world consequences. The work of the philosopher should not, or at least not solely, assess institutions based on a particular conception of justice, liberty, or another aim. Waldron adds that analytical political theorists 'must reflect also on the deeper layers of dignitarian value' (p. 9), such as respect and recognition. These values

(C) 2016 Macmillan Publishers Ltd. 1470-8914 Contemporary Political Theory Vol. 16, 4, 553-556 www.palgrave.com/journals 
shape people's expectations of their political institutions; hence they are intrinsic to institutions' normative value.

These claims are not necessarily new to those familiar with recent debates on political realism, practice-dependent methods, and non-ideal theory-a body of literature with which Waldron's engagement is rather brief and mostly limited to the work of Bernard Williams. He argues that Williams is interested in security rather than justice. Contrary to Waldron's interpretation, there is much on which they agree. Both authors align in their conceptual claims about the nature of 'the political' as a realm of disagreement requiring authoritative decision-makers. Moreover, both authors agree on the need to be more relevant for the actual endeavour of politics than has been the norm in the Anglo-Saxon analytical tradition. Arguably Waldron does not intend to add to the methodological side of these debates. Nevertheless, substantively, his interest in political institutions that can funnel disagreement in practice constitutes an invaluable contribution to these debates.

A suggestion for readers is that, after reading the first chapter, they turn to the final two chapters before delving into the second part of the book. These essays analyse the work of two twentieth century political theorists: Isaiah Berlin and Hannah Arendt, respectively. Both essays address how far these influential political theorists take political institutions seriously. Chapter 11, by Waldron's own admission (p. 289), is a polemic on the political thought of Berlin. The central substantive thrust of the chapter is that Berlin overlooks the importance of political institutions. Although agreeing with Berlin's analysis of value pluralism, his neglect of Enlightenment constitutionalism has impoverished British political thought, so claims Waldron (pp. 288-289). In stark contrast, chapter 12 celebrates the political thought of Hannah Arendt. According to Waldron, Arendt's insistence on 'the metaphor of the house' when theorising politics indicates the central importance of institutions in her thought. That claim might be controversial; Arendt has written much on extraconstitutional politics rather than ordinary everyday politics. Waldron's focus on the place of institutions in Arendt's political thought can account for this partial picture. The more important point of these essays is that they further explicate many of Waldron's commitments and concerns behind reflecting on political institutions and constitutional principles of modern democracies. The chapters in the middle of the book are Waldron's contribution to reintroducing them into contemporary political thought.

The 'second' part of the book-chapters 2 through 10-is a heterogeneous collection of essays on various democratic institutions. These chapters explore topics such as constitutionalism, bicameralism, accountability, and the majoritarian decision-making principle. Waldron uses different argumentative logics in his reflections. For instance, in his reflection on bicameralism (ch. 4), Waldron relies on arguments by canonical political philosophers, such as Locke and Montesquieu, to offer 'an anatomy lesson' (p. 91) on the different principles to decide between 
alternative modes of representation in the legislator. On the other hand, in chapter 9 on judicial review, Waldron explicitly avoids 'both [judicial review's] historical manifestations and questions about its particular effects' (p. 197) but starts his argument from an 'imagined society' (p. 203) instead. He thus advances a normative argument against judicial review. This diversity in topics and approaches results in a lack of consistency; but this is after all a collection of essays. One could also interpret the diversity as a strength; a focus on institutions can accommodate diverse normative political approaches. Substantively, the essays offer rich analyses of different norms behind democratic institutions, and while they may not always offer determinate answers, they always illuminate important normative issues.

Despite the diverse topics, and methods, a normative thread runs through these chapters. Waldron defends parliament as the legislative heart of modern mass democracy. Of course, his criticism of judicial review is well-known. But also when arguing for the dignity of the executive in the separation of powers (ch. 3), another upshot is that the legislator, that is parliament, should be autonomous from government. At several points, in this chapter and others, Waldron criticises the rise of executive power in modern democracies. This branch has been able to extract effective decision-making powers from the parliaments. His normative position thus defies empirical developments. However, as Waldron puts it, 'Even if the principle [of the separation of powers] is dying a sclerotic death, even if it misconceives the character of modern political institutions, it still points to something that was once deemed valuable ... and may still be valuable' (pp. 70-71).

From the generalizability of the substantive concern, Waldron's primary focus on Anglo-Saxon democracies (Great Britain, the United States, and to a lesser extent Canada, Australia, and New Zealand) might be seen as a problem. The rise of executive power is not limited to these democracies. Most modern democracies face an increasingly powerful executive. However, Waldron's Anglo-Saxon orientation effectively excludes interesting normative questions. For instance, how do and should multi-party systems on the European continent institutionalise the principle of loyal opposition? Or does this system (rightfully) prioritise another democratic principle? Waldron sometimes touches upon these differences but does not delve into them in a systematic way.

A central contribution of this book is its orientation toward a set of highly relevant questions of practical consequence for modern democracies. Although questions of justice and freedom raise important policy questions, such as about the need for a basic income or about privacy rights in a digital age, these questions tend to remain the object of on-going debate in deeply pluralistic societies. Authoritative democratic institutions needed to decide peacefully on these issues, however, can no longer be taken for granted. Notwithstanding Waldron's statist focus, we face immediate questions about how to legitimately institutionalise democratic politics 
in our age of globalisation. The recent Brexit illustrates that a legitimacy deficit can undermine the political institutions - in this case the European Union-needed for authoritative concerted action on such issues, even if the real-world solutions are often non-ideal compromises. These institutions are relevant because, in an age of mass migration, global capitalism, and transnational governance, concerns about justice and freedom are not contained within the boundaries of nation-states. The reorientation to political institutions is thus not merely valuable as a counterbalance to the contemporary preoccupation with conceptions of justice or other political aims. This reorientation also results in the theorisation of important questions facing democratic politics in the real world. Waldron's essays illustrate that these questions of institutional design are not normatively barren soil. Instead, his book shows that institutions can provoke insightful normative reflections. In sum, Political Political Theory offers an excellent and enjoyable read for political theorists with an interest in real-world politics.

Jan Pieter Beetz

VU University Amsterdam, 1081 HV Amsterdam, The Netherlands j.p.beetz@vu.nl 